\title{
RECEIVED
}

NUREG/CR-6473

JUL 081996

OSTI

\section{Global Positioning System \\ Reobservations over the \\ Eastern United States \\ Strain Monitoring Network}

\section{Prepared by}

W. E. Strange

National Geodetic Survey

National Oceanic and Atmospheric Administration

Prepared for

U.S. Nuclear Regulatory Commission 


\section{AVAILABILITY NOTICE}

Availability of Reference Materials Cited in NRC Publications

Most documents cited in NRC publications will be available from one of the following sources:

1. The NRC Public Document Room, 2120 L Street, NW., Lower Level, Washington, DC 20555-0001

2. The Superintendent of Documents, U.S. Government Printing Office, P. O. Box 37082, Washington, DC 20402-9328

3. The National Technical Information Service, Springfield, VA 22161-0002

Although the listing that follows represents the majority of documents cited in NRC publications, it is not intended to be exhaustive.

Referenced documents available for inspection and copying for a fee from the NRC Public Document Room include NRC correspondence and internal NRC memoranda; NRC bulletins, circulars, information notices, inspection and investigation notices; licensee event reports; vendor reports and correspondence; Commission papers; and applicant and licensee documents and correspondence.

The following documents in the NUREG series are available for purchase from the Government Printing Office: formal NRC staff and contractor reports, NRC-sponsored conference proceedings, international agreement reports, grantee reports, and NRC booklets and brochures. Also available are regulatory guides, NRC regulations in the Code of Federal Regulations, and Nuclear Regulatory Commission Issuances.

Documents available from the National Technical Information Service include NUREG-series reports and technical reports prepared by other Federal agencies and reports prepared by the Atomic Energy Commission, forerunner agency to the Nuclear Regulatory Commission.

Documents available from public and special technical libraries include all open literature items, such as books, journal articles, and transactions. Federal Register notices. Federal and State legisiation, and congressional reports can usually be obtained from these libraries.

Documents such as theses, dissertations, foreign reports and translations, and non-NRC conference proceedings are available for purchase from the organization sponsoring the publication cited.

Single copies of NRC draft reports are available free. to the extent of supply, upon written request to the Office of Administration, Distribution and Mail Services Section, U.S. Nuclear Regulatory Commission. Washington, DC 20555-0001.

Copies of industry codes and standards used in a substantive manner in the NRC regulatory process are maintained at the NRC Library. Two White Flint North, 11545 Rockville Pike, Rockville, MD 20852-2738, for use by the public. Codes and standards are usually copyrighted and may be purchased from the originating organization or, if they are American National Standards, from the American National Standards institute, 1430 Broadway, New York, NY 10018-3308.

\section{DISCLAJMER NOTICE}

This report was prepared as an account of work sponsored by an agency of the United States Government. Neither the United States Govemment nor any agency thereof, nor any of their employees, makes any warranty, expressed or implied, or assumes any legal liability or responsibility for any third party's use, or the results of such use, of any information, apparatus, product, or process disclosed in this report, or represents that its use by such third party would not infringe privately owned rights. 


\section{Global Positioning System \\ Reobservations over the \\ Eastern United States \\ Strain Monitoring Network}

Manuscript Completed: February 1996

Date Published: June 1996

\section{Prepared by}

W. E. Strange

National Geodetic Survey

National Oceanic and Atmospheric Administration

1315 East-West Highway

Silver Spring, MD 20910

E. Zurflueh, NRC Project Manager

\section{Prepared for}

Division of Engineering Technology

Office of Nuclear Regulatory Research

U.S. Nuclear Regulatory Commission

Washington, DC 20555-0001

NRC Job Code D1749 
DISCLAIMER

Portions of this document may be illegible in electronic image products. Images are produced from the best available original document. 



\section{ABSTRACT}

In the period March-May, 1990, a 45 station geodetic network, originally established in November-December, 1987, was reobserved using global positioning system (GPS) technology. This network, known as the Eastern U. S. Strain Network, was established for the purpose of determining strain and deformation in the central and eastern United States. This 1990 reobservation was the first of a series of reobservations scheduled to take place over a decade in order to place meaningful constraints on the small differential movements involved. 
CONTENTS

Abstract..................................... i i

List of Figures................................ vi

List of Tabres............................... vi

Introduction............................... 1

Description of the Reobservation Survey.............. 1

Data Reduction.............................. 8

Presentation and Discussion of Results............... 11 
IIST OF FIGURES

1. Eastern U.S. Strain Network.................. 2

\section{LIST OF TABLES}

1. Stations observed...................... 4

2. Final Observing Schedule, Field Team GPS Receivers. 6

3. Co-observations by Other Organizations.......... 7

4. Reference and Fiducial Stations Used in Data

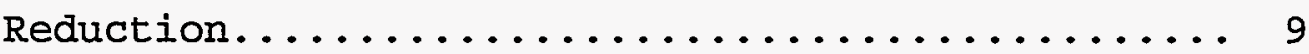

5. Reduction Results.................... 13

6. Comparison of Interstation Vectors............ 18

7. Comparison of 1987 and 1990 Interstation Vectors... 22 


\section{INTRODUCTION}

During the period 9 March to 21 May, 1990, the National Geodetic Survey (NGS) performed reobservations of a Global Position System (GPS) network originally established in 1987. This network, designated the Eastern U. S. Strain Network, spans the United States east of $105^{\circ}$ west longitude (Figure 1). The network was established in support of the Nuclear Regulatory Commission (NRC) for the purpose of monitoring crustal strain deformation. The 1990 reobservations are the first of a series of reobservations planned to span a period of a decade or more. Such Iong term monitoring is required because likely strain rates are very small and strain determinations accurate to about $1: 10^{8}$ are desired.

Results of the initial 1987 survey were reported by strange (1981). This report provides the results of the 1990 reobservations. Although some comparisons are made between the 1987 and 1990 surveys to evaluate the accuracies being achieved, no attempt is made to estimate strain rates. The time period between the two sets of observations of no more than 2.5 years is too short to allow meaningful strain estimates using only these two sets of determinations. Following a third set of observations in the late 1992 to late 1993 time frame there will be a separation of 5 to 6 years between observations and meaningful initial estimates of upper bounds can be placed on strain rates. However, it is still believed that a full decade of monitoring will be required to achieve the $1: 10^{8}$ level.

\section{DESCRIPTION OF THE REOBSERVATION SURVEY}

The Eastern U. S. Strain Network reobservation survey was planned and performed as an eleven (II) week effort by an observing team using five (5) Trimble SST receivers. During each weekly period, the team occupied five stations for a 5.5 hour session on three days. Each weekly period extended from Wednesday of one week through Tuesday of the following week. On Wednesday the observers traveled to the site. On Thursday arrangements were made and the site identified. Actual observations were performed on Friday, Monday, and Tuesday. The observations were planned to extend across the weekend in order to have additional time between observations. This was desirable to achieve maximum variability in weather conditions. The eleven sets of observations were tied together by having at least one station in every weekly station set included in another station set. Table 1 lists the stations observed and gives a set of abbreviated IDcodes which are used in the remainder of this report. The location of the stations is shown in Figure 1.

Table 2 gives the observation schedule undertaken by the National Geodetic Survey field team. During week 5, the Texas Department of Transportation co-observed at four stations. During week 6, 
the New Mexico Highway Department co-observed at three stations. These co-observations are summarized in Table 3. The purpose of scheduling three days of observations was to assure that even if something went wrong on one day, there would be at least two successful sets of observations at each station to achieve redundancy. This was achieved. Of the 165 station occupations planned, the field team achieved a $95 \%$ success rate. Of the eight station occupations that were unsuccessful, five involved stations that were observed in more than one weekly period so that only three of the stations occupied by the NGS field teams had less than three successful occupations. These stations were Hyde, Ays 2, and Westford (OCP3). In the case of Westford (OCP3), the observations from the Westford CIGNET station were used to support orbit adjustment. Since Westford CIGNET station and OCP3 are strongly connected, the Westford site was represented by numerous observations.

During the 1990 reobservation campaign, all but four of the stations observed during the original 1987 survey were reoccupied. In two of these four cases, another point which has been closely tied to the original station was observed at the site. Thus, there should be negligible loss of accuracy at these sites from changing stations. At Richmond, Florida, data was used from the Richmond CIGNET antenna rather than a receiver placed over the ground monument, TIMER. These have been accurately connected with local GPS surveys. At Ft. Davis, Texas, the monument Harvard RM 3 was occupied, rather than the monument Harvard RM 4 which was occupied in 1987. This was done because Harvard RM 4 was not available for occupation. However, these two monuments have been interconnected at the few millimeter level using ground survey.

The original station occupied at Lubbock had been destroyed, and a new station established by the Texas Department of Transportation at the site was occupied. At the time of the 1990 survey, it had not been possible to reduce the data from station Bravo near Minneapolis, Minnesota. It was feared that the cause of the problem was interference from active radar units at the site, which was on a military base. Therefore, it was decided to move to a nearby site at Riverside, Wisconsin, which was a part of the Wisconsin High Accuracy Reference Network. Subsequent to the 1990 survey, a way was found to process the 1987 data from station Bravo, and it is no longer believed that the problem was active radars. During future surveys, it is anticipated that both Bravo and Riverside will be occupied.

In addition to the data observed by the field teams, data taken by stations of the Cooperative International GPS Network (CIGNET) located at Westford, Massachusetts; Richmond, Florida; and Mojave, California were used to support satellite orbit adjustment during the reduction phase. The stations were occupied by Minimac receivers. 
TABLE 1

STATIONS OBSERVED

\begin{tabular}{|c|c|c|}
\hline STATION NAME & ID-CODE & STATE OF LOCATION \\
\hline ALBERG & ALBU & VERMONT \\
\hline AMARILLO & AMAR & TEXAS \\
\hline ARP2 & ARP2 & NEW YORK \\
\hline ASHCOPORT & ASHC & OHIO \\
\hline ASTRO & ASTW & VIRGINIA \\
\hline AUSTIN & AUST & TEXAS \\
\hline BEARTOWN & BEAR & PENNSYLVANIA \\
\hline BEAUMONT & BEAU & TEXAS \\
\hline BLOOMINGTON & BLOO & INDIANA \\
\hline BLUFFPORT & BLUF & MISSOURI \\
\hline BOLTON & BOLT & OHIO \\
\hline BRINKLEY & BRIN & ARKANSAS \\
\hline BRONSON & BRON & MISSISSIPPI \\
\hline CHEYENNE & 1169 & WYOMING \\
\hline EL PASO & ELPA & TEXAS \\
\hline FARM & FARM & LOUISIANA \\
\hline FLNR & FLNR & FLORIDA \\
\hline FREEMAN & FREE & MICHIGAN \\
\hline FT DAVIS 2 & HAR3 & TEXAS \\
\hline FUTRELL & FUTZ & NORTH CAROLINA \\
\hline GPS37 & GP37 & TENNESSEE \\
\hline GPS47 & GP47 & TENNESSEE \\
\hline GPS57 & GP57 & TENNESSEE \\
\hline GREENBANK & T007 & WEST VIRGINIA \\
\hline HAPGOOD & HAGO & SOUTH CAROLINA \\
\hline K169 & K169 & MAINE \\
\hline LAS CRUCES & LACR & NEW MEXICO \\
\hline LEONARD & LEON & OKLAHOMA \\
\hline
\end{tabular}




\begin{tabular}{|c|c|c|}
\hline STATION NAME & ID-CODE & STATE OF LOCATION \\
\hline LIME & LIME & MAINE \\
\hline LINCOLN & LINC & NEBRASKA \\
\hline LUBBOCK 2 & LUB2 & TEXAS \\
\hline MARYLAND POINT & MDPT & MARYLAND \\
\hline MCDAVID & MCDA & FLORIDA \\
\hline MILES CITY & MILE & MONTANA \\
\hline NEW CARROLLTON & CARR & GEORGIA \\
\hline NMB1 & NMB1 & NEW MEXICO \\
\hline NORTH LIBERTY & NOLI & IOWA \\
\hline ODESSA & ODES & TEXAS \\
\hline PIERRE & HYDE & SOUTH DAKOTA \\
\hline PLATTVILLE & PLAT & COLORADO \\
\hline PRINCETON & PRIN & NEW JERSEY \\
\hline RICHMOND CIGNET & $\mathrm{RICH}$ & FLORIDA \\
\hline RIVERSIDE & RIVR & WISCONSIN \\
\hline ROCK & ROCK & WISCONSIN \\
\hline ROSWELL & Rosw & NEW MEXICO \\
\hline STANPORT & STAN & KENTUCKY \\
\hline STATESPORT & STAT & NORTH CAROLINA \\
\hline TAOS & TAOS & NEW MEXICO \\
\hline WALTPORT & WALT & SOUTH CAROLINA \\
\hline WESTFORD & OCP3 & MASSACHUSETTS \\
\hline WILLIAMSON & WILL & ILLINOIS \\
\hline
\end{tabular}


TABIE 2

FINAI OBSERVING SCHEDULE

FIELD TEAM GPS RECEIVERS

\begin{tabular}{|c|c|c|c|c|c|c|}
\hline $\begin{array}{l}\text { OBSERVING } \\
\text { WEEK }\end{array}$ & DAY & \multicolumn{5}{|c|}{$\begin{array}{l}\text { STATIONS OCCUPIED } \\
\text { (FOUR CHARACTER ID-CODE) }\end{array}$} \\
\hline \multirow{3}{*}{1} & 68 & MCDA & CARR & FLNR & FARM & BRON \\
\hline & 71 & MCDA & CARR & FLNR & FARM & BRON \\
\hline & 72 & MCDÁ & CARR & FLNR & FARM & BRON \\
\hline \multirow{3}{*}{2} & 75 & STAT & CARR & WALT & FUTZ & HAGO \\
\hline & 78 & STAT & CARR & WALT & FUTZ & HAGO \\
\hline & 79 & STAT & CARR & WALT & FUTZ & HAGO \\
\hline \multirow{3}{*}{3} & 82 & GP57 & CARR & GP37 & (1) & GP47 \\
\hline & 85 & GP57 & CARR & GP37 & BRIN & GP47 \\
\hline & 86 & GP57 & CARR & GP37 & BRIN & GP47 \\
\hline \multirow{3}{*}{4} & 89 & WILL & LEON & BLUF & BRIN & GP47 \\
\hline & 92 & WILL & LEON & BLUF & BRIN & GP47 \\
\hline & 93 & WILL & LEON & BLUF & BRIN & GP47 \\
\hline \multirow{3}{*}{5} & 96 & (2) & LEON & AMAR & AUST & ODES \\
\hline & 99 & FARM & LEON & AMAR & AUST & ODES \\
\hline & 100 & FARM & LEON & AMAR & AUST & ODES \\
\hline \multirow{3}{*}{6} & 103 & (3) & 1169 & AMAR & NMBI & ODES \\
\hline & 106 & PLAT & 1169 & AMAR & $\mathrm{NMBI}$ & ODES \\
\hline & 107 & PLAT & 1169 & AMAR & NMBI & ODES \\
\hline \multirow{3}{*}{7} & 110 & PLAT & MILE & HYDE & LINC & RIVE \\
\hline & 113 & PLAT & MILE & (2) & LINC & RIVE \\
\hline & 114 & PLAT & MILE & HYDE & LINC & RIVE \\
\hline \multirow{3}{*}{8} & 117 & WILL & BLOO & FREE & NOLI & ROCK \\
\hline & 119 & WILL & BLOO & FREE & NOLI & ROCK \\
\hline & 120 & WILL & BLOO & FREE & NOLI & ROCK \\
\hline \multirow{3}{*}{9} & 123 & STAN & BLOO & BOLT & (1) & ASHC \\
\hline & 126 & STAN & BLOO & BOLT & T007 & ASHC \\
\hline & 127 & STAN & BLOO & BOLT & T007 & ASHC \\
\hline
\end{tabular}




\begin{tabular}{|c|c|c|c|c|c|c|}
\hline $\begin{array}{c}\text { OBSERVING } \\
\text { WEEK }\end{array}$ & DAY & \multicolumn{5}{|c|}{$\begin{array}{c}\text { STATIONS OCCUPIED } \\
\text { (FOUR CHARACTER ID-CODE) }\end{array}$} \\
\hline \multirow{3}{*}{10} & 130 & PRIN & ASTW & MDPT & TOO7 & BEAR \\
\cline { 2 - 7 } & 133 & PRIN & ASTW & MDPT & TOO7 & BEAR \\
\cline { 2 - 7 } & 134 & PRIN & ASTW & MDPT & (4) & BEAR \\
\hline \multirow{3}{*}{11} & 137 & ARP2 & K169 & LIME & ALBU & OCP3 \\
\cline { 2 - 7 } & 140 & ARP2 & K169 & LIME & ALBU & OCP3 \\
\cline { 2 - 7 } & 141 & (1) & K169 & LIME & ALBU & (5) \\
\hline
\end{tabular}

(1) Instrument problems

(2) Session aborted due to lightning danger

(3) Unexpected locked gate prevented access

(4) Operator illness prevented observations

(5) Station already occupied by other group

TABLE 3

CO-OBSERVATIONS BY OTHER ORGANIZATIONS

\begin{tabular}{|}
\begin{tabular}{|c|c|c|c|c|c|}
\hline $\begin{array}{c}\text { OBSERVING } \\
\text { WEEK }\end{array}$ & DAY & \multicolumn{4}{|c|}{$\begin{array}{c}\text { STATIONS OCCUPIED } \\
\text { (FOUR CHARACTER ID-CODE) }\end{array}$} \\
\hline 5 & 99 & ELPA & LUB2 & BEAU & HRM3 \\
\cline { 2 - 6 } & 100 & ELPA & LUB2 & BEAU & HRM3 \\
\hline \multirow{2}{*}{6} & 103 & TAOS & LACR & ROSW & \\
\cline { 2 - 7 } & 106 & TAOS & LACR & ROSW & \\
\cline { 2 - 7 } & 107 & TAOS & LACR & ROSW & \\
\hline
\end{tabular}
\end{tabular}


As was the case with the original 1987 survey, data reduction was performed using the OMNI reduction program with simultaneous solution for differential station positions and improved satellite orbital elements. Using this procedure, the positions of at least two, and preferably three, stations, in addition to the reference station, must be held fixed to allow the orbital improvement to be performed. This was accomplished by including in the reductions data from the three CIGNET stations which are co-located with Very Long Baseline Interferometry (VIBI) stations that monitor time variation of positions.

The preferred solution mode was to use one of the stations occupied by the field team as the reference station for a solution and to hold fixed the positions of the CIGNET stations so that they could serve as fiducial stations. The parameters solved for were then: differential positions between the reference station and the other field stations, corrections to the satellite orbital elements, a tropospheric refraction parameter for each station, and initial satellite integer constants. The station chosen for the reference station for a session was, wherever possible, a station that had previously been occupied by GPS.

Because of failures of equipment at the CIGNET stations, it was not always possible to process the results as originally planned. There were a total of 33 observing sessions. Of these, 17 sessions could be processed using data from all three CIGNET stations. An additional seven sessions could be processed using data from two of the three CIGNET stations. Of the remaining nine sessions, five sessions were processed using one CIGNET station and using one of the stations occupied by a field receiver to act as a fiducial station. Four sessions could not be processed because none of the CIGNET stations had usable data. Table 4 gives the reference station and fiducial stations used in processing each session.

In three of the five instances where a field receiver was used as a fiducial station, the receiver was co-located at a station with repeat VLBI measurements which could provide a means of defining station motion. This was the case when using Harvard RM 3 located at Ft. Davis, Texas, as a fiducial station for days 99 and 100, and when using the platville station on day 106 . In the case of the use of station Farm on days 68 and 71 , the position for Farm derived for reductions of days 96, 99, and 100 where a position for Farm was computed. 
TABLE 4

REFERENCE AND FIDUCIAL STATIONS

USED IN DATA REDUCTION

\begin{tabular}{|c|c|c|}
\hline DAY & REFERENCE STATION & FIDUCIAL STATIONS \\
\hline 68 & CARROLLTON & MOJAVE, FARM \\
\hline 71 & RICHMOND & MOJAVE, FARM \\
\hline 72 & CARROLLTON & RICHMOND, MOJAVE \\
\hline 75 & \multicolumn{2}{|c|}{ NOT PROCESSED } \\
\hline 78 & CARROLLTON & RICHMOND, WESTFORD \\
\hline 79 & CARROLLTON & RICHMOND, WESTFORD, MOJAVE \\
\hline 82 & CARROLLTON & RICHMOND, WESTFORD, MOJAVE \\
\hline 85 & CARROLLTON & RICHMOND, WESTFORD, MOJAVE \\
\hline 86 & CARROLLTON & RICHMOND, WESTFORD, MOJAVE \\
\hline 89 & \multicolumn{2}{|c|}{ NOT PROCESSED } \\
\hline 92 & LEONARD & RICHMOND, WESTFORD, MOJAVE \\
\hline 93 & LEONARD & RICHMOND, WESTFORD, MOJAVE \\
\hline 96 & LEONARD & RICHMOND, WESTFORD \\
\hline 99 & LEONARD & FT. DAVIS, MOJAVE \\
\hline 100 & LEONARD & FT. DAVIS, MOJAVE \\
\hline 103 & NMBI & RICHMOND, MOJAVE \\
\hline 106 & NMBI & MOJAVE, PLATTVILLE \\
\hline 107 & PLATTVILLE & RICHMOND, MOJAVE \\
\hline 110 & PLATTVILLE & MOJAVE, RICHMOND, WESTFORD \\
\hline 113 & PLATTVILLE & MOJAVE, RICHMOND, WESTFORD \\
\hline 114 & PLATTVILLE & MOJAVE, RICHMOND, WESTFORD \\
\hline 117 & BLOOMINGTON & MOJAVE, RICHMOND, WESTFORD \\
\hline 119 & \multicolumn{2}{|c|}{ NOT PROCESSED } \\
\hline 120 & BLOOMINGTON & MOJAVE, RICHMOND, WESTFORD \\
\hline 123 & BLOOMINGTON & MOJAVE, RICHMOND, WESTFORD \\
\hline 126 & BLOOMINGTON & MOJAVE, RICHMOND, WESTFORD \\
\hline 127 & BLOOMINGTON GREEN BANK & MOJAVE, RICHMOND, WESTFORD \\
\hline 130 & T007 & MOJAVE, RICHMOND, WESTFORD \\
\hline
\end{tabular}




\begin{tabular}{|l|l|l|}
\hline DAY & \multicolumn{1}{|c|}{ REFERENCE STATION } & \multicolumn{1}{|c|}{ FIDUCIAL STATIONS } \\
\hline 133 & MARYLAND POINT & MOJAVE, WESTFORD \\
\hline 134 & MARYLAND POINT & MOJAVE, RICHMOND, WESTFORD \\
\hline 137 & HAYSTACK OCP3 & MOJAVE, RICHMOND \\
\hline 140 & HAYSTACK OCP3 & MOJAVE, RICHMOND, WESTFORD \\
\hline 141 & \multicolumn{2}{|c|}{ NOT PROCESSED } \\
\hline
\end{tabular}


Table 5 presents the final results of the data reductions in the form of differential vectors between stations. The differential vectors are presented in the form of $\Delta \mathrm{x}, \Delta \mathrm{y}, \Delta \mathrm{z}$. It is premature to try to determine strains from two sets of data (the 1987 and 1990 surveys) which are only about 2.5 years apart in time. However, it is worthwhile to perform some comparisons to evaluate the accuracy being achieved and the level of accuracy to be anticipated for strain determinations over a time period of 5 to 6 years (i.e. following the next set of observations) and from a full decade of observations.

The most meaningful parameter to use in evaluating deformation over the time periods 1987 to 1993 (and 1987 to 1997) will be changes in the length of interstation vectors. This is true for two reasons. First, the greatest interest in the monitoring of the eastern United States is strain as determined from changes in differential horizontal position between stations. The use of interstation vector length largely eliminates the effects of errors in the station height determination, the most weakly determined parameter. Second, the use of interstation vector length eliminates the impact of small coordinate system translations and rotations on the results. This is important because the maintaining of exact coordinate system agreement over a decade will be very difficult. This is particularly the case with the 1987 and 1990 surveys where orbit adjustments are necessary and different sets of fiducial stations are, of necessity, used in data reduction. Therefore, the comments which follow are based on comparisons of interstation vector lengths.

Table 6 presents comparisons of interstation vector lengths for the repeat differential positions presented in Table 5 . Results are presented for 42 baselines. For the 1990 results given in Table 6 , the maximum spread in repeat baseline length determinations is less than $6 \mathrm{~cm}$ for 80 percent of the baselines. In no case does the maximum spread exceed $9.5 \mathrm{~cm}$. In four of the eight instances where the maximum spread exceeds $6 \mathrm{~cm}$, there are three determinations with two of the three agreeing rather closely and the other being the outlier. The degree of baseline repeatability in the raw results suggests that, with careful examination of a few outliers so that they can be either rejected or improved, the lengths of 90 percent of the baselines can be determined to the 2 or $3 \mathrm{~cm}$ accuracy level.

Another way to evaluate accuracy is to compare 1987 and 1990 results. While the time interval is not adequate to give definitive strain rate estimates, comparisons of determinations at the two epochs can give another measure of accuracy for baselines. Geophysical considerations and measurements using VLBI lead to the expectation that strain deformation in the 
eastern United States is not in excess of a few parts in $10^{8}$ per year at most. Thus differences of no more than a few centimeters between the 1987 and 1990 determinations for baselines in the 200 to $500 \mathrm{~km}$ length range would be expected.

Table 7 gives a comparison of mean baseline lengths for the 1987 and 1990 determinations. The ten baselines used in this table are baselines which were directly measured in both 1987 and 1990, as contrasted to baselines derived indirectly from differencing the positions measured for two stations. The differences between 1987 and 1990 mean values shown in Table 7 are compatible with strain rate determinations at the few parts in $10^{8}$ per year level over an 8- to 10-year period, the approximate planned duration of this experiment. The only excessively large difference between means is the $8.3 \mathrm{~cm}$ value for the CARR to GPS57 baseline. As may be seen from Table 7 , this is the result of a single bad baseline estimate made in 1987. Thus 50 of the 51 baseline determinations shown in Table 7 are accurate enough to support satisfactory strain rate determinations.

With four epochs of measurement planned for this experiment, there should be no problem in identifying and eliminating a small percentage of outliers to provide satisfactory strain rate estimates. This is particularly true because extremely accurate orbit data will be available for the remaining two observation epochs of the experiment. Therefore, it will not be necessary to depend upon the availability of local reference station data to perform orbit adjustments simultaneously with the station position estimates. The availability of the accurate orbits will substantially increase the accuracy of baseline computations for the final two epochs of baseline determination. 
TABLE 5

REDUCTION RESULTS

\begin{tabular}{|c|c|c|c|c|c|c|}
\hline WEEK & DAY & REF STATION & TO STATIONS & $\Delta x(m)$ & $\Delta y(m)$ & $\Delta \mathrm{z}(\mathrm{m})$ \\
\hline \multirow[t]{3}{*}{1} & 68 & CARR & BRON & -435970.351 & -154538.705 & -213230.574 \\
\hline & & & FLNR & -286920.801 & -201553.264 & -377739.176 \\
\hline & & & MCDA & -199338.446 & -173021.971 & -253637.899 \\
\hline \multirow[t]{2}{*}{1} & 71 & $\mathrm{RICH}$ & FLNR & -220868.022 & 172015.616 & 388929.287 \\
\hline & & & MCDA & -707127.252 & 200546.941 & 513030.578 \\
\hline \multirow[t]{3}{*}{1} & 72 & CARR & BRON & -435970.381 & -154538.705 & -213230.574 \\
\hline & & & FLNR & 286920.736 & -201553.326 & -377739.117 \\
\hline & & & MCDA & -199338.492 & -173022.003 & -253637.836 \\
\hline \multirow[t]{4}{*}{2} & 78 & CARR & FUTZ & 688822.530 & 291811.543 & 260141.028 \\
\hline & & & HAGO & 413003.579 & 82268.953 & 44541.547 \\
\hline & & & STAT & 361347.455 & 183436.195 & 199934.128 \\
\hline & & & WALT & 418229.401 & 12661.306 & -60577.349 \\
\hline \multirow[t]{7}{*}{3} & 82 & CARR & GP37 & -20567.118 & 125311.746 & 183532.780 \\
\hline & & & GP47 & -415958.350 & 107988.379 & 184110.356 \\
\hline & & & GP57 & -316900.387 & 84874.637 & 149432.615 \\
\hline & 85 & CARR & GP37 & -20567.151 & 125311.826 & 183532.797 \\
\hline & & & GP47 & -415958.398 & 107988.464 & 184110.333 \\
\hline & & & GP57 & -316900.439 & 84874.730 & 149432.590 \\
\hline & & & BRIN & -560903.993 & 63771.881 & 120106.265 \\
\hline \multirow[t]{4}{*}{3} & 86 & CARR & GP37 & -20567.057 & 125311.797 & 183532.748 \\
\hline & & & GP47 & -415958.348 & 107988.389 & 184110.320 \\
\hline & & & GP57 & -316900.391 & 84874.714 & 149432.562 \\
\hline & & & BRIN & -560903.975 & 63771.859 & 120106.234 \\
\hline \multirow[t]{3}{*}{4} & 92 & LEON & WILL & 609095.185 & 96759.752 & 163309.382 \\
\hline & & & BLUF & 493309.487 & 30169.587 & 76571.151 \\
\hline & & & BRIN & 414848.247 & -91058.052 & -92838.653 \\
\hline
\end{tabular}




\begin{tabular}{|c|c|c|c|c|c|c|}
\hline WEEK & DAY & REF STATION & TO STATIONS & $\Delta x(m)$ & $\Delta y(m)$ & $\Delta z(m)$ \\
\hline & & & GP47 & 559793.842 & -46841.487 & -28834.579 \\
\hline \multirow[t]{4}{*}{4} & 93 & LEON & WILL & 609095.282 & 96759.858 & 163309.326 \\
\hline & & & BLUF & 493309.558 & 30169.669 & 76571.107 \\
\hline & & & BRIN & 414848.266 & -91057.993 & 92838.696 \\
\hline & & & GP47 & 559793.876 & -46841.411 & -28834.617 \\
\hline \multirow[t]{4}{*}{5} & 96 & LEON & FARM & 235938.318 & -215932.745 & -288898.924 \\
\hline & & & AMAR & -549575.584 & 39130.404 & -62462.612 \\
\hline & & & AUST & -215562.207 & -314215.333 & -517161.865 \\
\hline & & & ODES & -634211.095 & -151658.218 & -371002.674 \\
\hline \multirow[t]{7}{*}{5} & 99 & LEON & FARM & 235938.363 & -215932.883 & -288898.875 \\
\hline & & & AMAR & -549575.595 & 39130.463 & -62462.599 \\
\hline & & & AUST & -215562.219 & -314215.371 & -517161.873 \\
\hline & & & ODES & -634211.109 & -151658.192 & -371002.713 \\
\hline & & & ELPA & -1026233.150 & -49841.209 & -369310.607 \\
\hline & & & LUB2 & -566732.012 & -65111.858 & -217047.646 \\
\hline & & & BEAU & 119995.755 & -358948.042 & -534359.378 \\
\hline \multirow[t]{7}{*}{5} & 100 & LEON & FARM & 235938.390 & -215932.836 & -288898.904 \\
\hline & & & AMAR & -549575.584 & 39130.563 & -62462.701 \\
\hline & & & AUST & -215562.162 & -314215.439 & -517161.849 \\
\hline & & & ODES & -634211.090 & -151658.107 & -371002.773 \\
\hline & & & ELPA & -1026233.140 & -49841.159 & -369310.625 \\
\hline & & & LUB2 & -566731.996 & -65111.815 & -217047.670 \\
\hline & & & BEAU & 119995.804 & -358947.989 & -534359.443 \\
\hline \multirow[t]{5}{*}{6} & 103 & NMBI & 1169 & 260439.597 & 359657.453 & 532315.560 \\
\hline & & & AMAR & 423350.886 & -95770.610 & 15129.116 \\
\hline & & & ODES & 338715.408 & -286559.261 & -293411.033 \\
\hline & & & TAOS & 107614.291 & 64169.020 & 128104.905 \\
\hline & & & LACR & -76273.045 & -154005.010 & -254957.548 \\
\hline
\end{tabular}




\begin{tabular}{|c|c|c|c|c|c|c|}
\hline WEEK & DAY & REF STATION & TO STATIONS & $\Delta \mathbf{x}(\mathbf{m})$ & $\Delta y(m)$ & $\Delta z(m)$ \\
\hline & & & ROSW & 156081.928 & -154592.635 & -158515.178 \\
\hline & & & PLAT & 254449.950 & 290321.409 & 451921.029 \\
\hline \multirow[t]{6}{*}{6} & 106 & $\mathrm{NMBl}$ & 1169 & 260439.671 & 359657.322 & 532315.549 \\
\hline & & & AMAR & 423350.876 & -95770.760 & 15129.176 \\
\hline & & & ODES & 338715.358 & -286559.379 & -293410.915 \\
\hline & & & TAOS & 107614.304 & 64168.942 & 128104.936 \\
\hline & & & LACR & -76273.115 & -154005.044 & -254957.471 \\
\hline & & & Rosw & 156081.898 & -154592.734 & -158515.089 \\
\hline \multirow[t]{7}{*}{6} & 107 & PLAT & 1169 & 5989.728 & 69335.918 & 80394.515 \\
\hline & & & AMAR & 168900.966 & -386092.024 & -436791.943 \\
\hline & & & LACR & -330723.028 & -444326.386 & -706878.562 \\
\hline & & & NMBI & -254449.941 & -290321.366 & -451921.064 \\
\hline & & & ODES & 84265.405 & -576880.673 & -745332.019 \\
\hline & & & Rosw & -98368.045 & -444914.056 & -610436.181 \\
\hline & & & TAOS & -146835.629 & -226152.425 & -323816.132 \\
\hline \multirow[t]{11}{*}{7} & 110 & PLAT & MILE & 36266.759 & 481231.239 & 501773.271 \\
\hline & & & HYDE & 423401.235 & 228184.733 & 344677.185 \\
\hline & & & LINC & 675642.872 & -84658.180 & 48084.051 \\
\hline & & & RIVR & 1062987.820 & 289824.434 & 475136.510 \\
\hline & 113 & PLAT & MILE & 36266.751 & 481231.279 & 501773.235 \\
\hline & & & LINC & 675642.848 & -84658.245 & 48084.112 \\
\hline & & & RIVR & 1062987.830 & 289824.423 & 475136.500 \\
\hline & 114 & PLAT & MILE & 36266.759 & 481231.265 & 501773.229 \\
\hline & & & HYDE & 423401.214 & 228184.740 & 344677.169 \\
\hline & & & LINC & 675642.840 & -84658.220 & 48084.094 \\
\hline & & & RIVR & 1062987.820 & 289824.411 & 475136.509 \\
\hline \multirow[t]{2}{*}{8} & 117 & BLOO & ROCK & -261867.087 & 284935.532 & 336057.573 \\
\hline & & & NOLI & -433296.753 & 179440.398 & 218980.223 \\
\hline
\end{tabular}




\begin{tabular}{|c|c|c|c|c|c|c|}
\hline WEEK & DAY & REF STATION & TO STATIONS & $\Delta x(m)$ & $\Delta y(\mathbf{m})$ & $\Delta z(m)$ \\
\hline & & & WILL & -215520.797 & -107218.039 & -124446.720 \\
\hline & & & FREE & 174536.657 & 334051.090 & 362012.295 \\
\hline \multirow[t]{4}{*}{8} & 120 & BLOM & ROCK & -261867.095 & 284935.538 & 336057.534 \\
\hline & & & NOLI & -433296.778 & 179440.378 & 218980.206 \\
\hline & & & WILL & -215520.838 & -107218.109 & -124446.680 \\
\hline & & & FREE & 174536.646 & 334051.029 & 362012.318 \\
\hline \multirow[t]{11}{*}{9} & 123 & BLOM & ASHC & 467367.129 & 240807.852 & 219663.688 \\
\hline & & & BOLT & 281755.427 & 76017.056 & 60999.398 \\
\hline & & & STAN & 238231.602 & -72094.038 & -115579.095 \\
\hline & 126 & BLOM & ASHC & 467367.129 & 240807.850 & 219663.711 \\
\hline & & & BOLT & 281755.413 & 76017.081 & 60999.445 \\
\hline & & & STAN & 238231.604 & -72094.035 & -115579.074 \\
\hline & & & T007 & 580839.192 & 17256.075 & -63841.308 \\
\hline & 127 & BLOM & ASHC & 467367.152 & 240807.792 & 219663.753 \\
\hline & & & BOLT & 281755.432 & 76017.056 & 60999.449 \\
\hline & & & STAN & 238231.607 & -72094.089 & -115579.050 \\
\hline & & & T007 & 580839.213 & 17256.113 & -63841.349 \\
\hline \multirow[t]{7}{*}{10} & 130 & T007 & MDPT & 227234.678 & 41469.951 & -6062.185 \\
\hline & & & PRIN & 403312.204 & 233522.102 & 167720.849 \\
\hline & & & ASTW & 213824.375 & 27198.711 & -20952.397 \\
\hline & & & BEAR & 297893.633 & 182318.816 & 141178.767 \\
\hline & 133 & MDPT & T007 & -223336.189 & -41470.015 & 6062.177 \\
\hline & & & PRIN & 179975.903 & 192052.186 & 173783.006 \\
\hline & & & ASTW & -9511.893 & -14271.272 & -14890.171 \\
\hline \multirow[t]{3}{*}{10} & 134 & MDPT & PRIN & 179975.957 & 192052.137 & 173783.055 \\
\hline & & & ASTW & -9511.906 & -14271.216 & -14890.217 \\
\hline & & & BEAR & 74557.374 & 140848.915 & 147240.941 \\
\hline 11 & 137 & OCP3 & ALBU & -191490.945 & 123505.462 & 183331.008 \\
\hline
\end{tabular}




\begin{tabular}{|l|l|l|l|l|r|r|}
\hline WEEK & DAY & REF STATION & \multicolumn{1}{|c|}{ TO STATIONS } & \multicolumn{1}{c|}{$\Delta \mathrm{x}(\mathrm{m})$} & \multicolumn{1}{c|}{$\Delta \mathrm{y}(\mathrm{m})$} & \multicolumn{1}{c|}{$\Delta \mathrm{z}(\mathrm{m})$} \\
\hline & & & ARP2 & -382200.493 & -2785.685 & 110635.234 \\
\hline & & & K169 & 216449.208 & 225142.633 & 143477.931 \\
\hline & & & LIME & 160382.480 & 349567.312 & 278862.401 \\
\hline & 140 & OCP3 & ALBU & -191490.905 & 123505.459 & 183330.918 \\
\hline & & & ARP2 & -382200.470 & -2785.713 & 110635.156 \\
\hline & & & K169 & 216449.181 & 225142.750 & 143477.773 \\
\hline & & & LIME & 160382.470 & 349567.264 & 278862.376 \\
\hline
\end{tabular}


TABLE 6

COMPARISON OF INTERSTATION VECTORS

(VECTOR LENGTH IN METERS)

\begin{tabular}{|c|c|c|c|}
\hline FROM & TO & DAY & VECTOR LENGTH \\
\hline \multirow[t]{2}{*}{ CARR } & BRONSON & 68 & 509332.540 \\
\hline & & 72 & .565 \\
\hline \multirow[t]{3}{*}{ CARR } & FLNR & 68 & 515397.079 \\
\hline & & 71 & .074 \\
\hline & & 72 & .024 \\
\hline \multirow[t]{3}{*}{ CARR } & MCDAVID & 68 & 366066.391 \\
\hline & & 71 & .408 \\
\hline & & 72 & .387 \\
\hline \multirow[t]{2}{*}{ CARR } & FUTRELL & 78 & 792025.132 \\
\hline & & 79 & .132 \\
\hline \multirow[t]{2}{*}{ CARR } & HAGOOD & 78 & 423466.748 \\
\hline & & 79 & .724 \\
\hline \multirow[t]{2}{*}{ CARR } & STATESPORT & 78 & 451878.829 \\
\hline & & 79 & .811 \\
\hline \multirow[t]{2}{*}{ CARR } & WALTPORT & 78 & 422783.344 \\
\hline & & 79 & .287 \\
\hline \multirow[t]{3}{*}{ CARR } & GPS37 & 82 & 223182.260 \\
\hline & & 85 & .322 \\
\hline & & 86 & .257 \\
\hline \multirow[t]{3}{*}{ CARR } & GPS47 & 82 & 467524.825 \\
\hline & & 85 & .878 \\
\hline & & 86 & .812 \\
\hline \multirow[t]{3}{*}{ CARR } & GPS57 & 82 & 360499.190 \\
\hline & & 85 & .247 \\
\hline & & 86 & .189 \\
\hline \multirow[t]{2}{*}{ CARR } & BRINKLEY & 85 & 577153.062 \\
\hline & & 86 & .036 \\
\hline
\end{tabular}




\begin{tabular}{|c|c|c|c|}
\hline FROM & TO & DAY & VECTOR LENGTH \\
\hline \multirow[t]{2}{*}{ LEONARD } & WILLIAMSON & 92 & 637988.517 \\
\hline & & 93 & .612 \\
\hline \multirow[t]{2}{*}{ LEONARD } & BLUFFPORT & 92 & 500127.579 \\
\hline & & 93 & .647 \\
\hline \multirow[t]{2}{*}{ LEONARD } & BRINLEY & 92 & 434752.404 \\
\hline & & 93 & .419 \\
\hline \multirow[t]{2}{*}{ LEONARD } & GP47 & 92 & 562489.736 \\
\hline & & 93 & .766 \\
\hline \multirow[t]{3}{*}{ LEONARD } & FARM & 96 & 430994.697 \\
\hline & & 99 & .758 \\
\hline & & 100 & .782 \\
\hline \multirow[t]{3}{*}{ LEONARD } & AMARILLO & 96 & 554496.248 \\
\hline & & 99 & .262 \\
\hline & & 100 & .269 \\
\hline \multirow[t]{3}{*}{ LEONARD } & AUSTIN & 96 & 642382.079 \\
\hline & & 99 & .108 \\
\hline & & 100 & .103 \\
\hline \multirow[t]{3}{*}{ LEONARD } & ODESSA & 96 & 750244.568 \\
\hline & & 99 & .594 \\
\hline & & 100 & .591 \\
\hline \multirow[t]{3}{*}{ NMBI } & $\begin{array}{l}1169 \\
\text { CHEYENNE }\end{array}$ & 103 & 693211.456 \\
\hline & & 106 & .482 \\
\hline & & 107 & .410 \\
\hline \multirow[t]{3}{*}{ NMBI } & AMARILLO & 103 & 434311.953 \\
\hline & & 106 & .978 \\
\hline & & 107 & .984 \\
\hline \multirow[t]{2}{*}{ NMBI } & ODESSA & 103 & 531915.756 \\
\hline & & 106 & .723 \\
\hline
\end{tabular}




\begin{tabular}{|c|c|c|c|}
\hline FROM & To & DAY & VECTOR LENGTH \\
\hline & & 107 & .699 \\
\hline \multirow[t]{3}{*}{ PLATTVILLE } & MILES CITY & 110 & 696186.181 \\
\hline & & 113 & .182 \\
\hline & & 114 & .169 \\
\hline \multirow[t]{2}{*}{ PLATTVILLE } & HYDE & 110 & 591725.646 \\
\hline & & 114 & .624 \\
\hline \multirow[t]{3}{*}{ PLATTVILLE } & LINCOLN & 110 & 682621.692 \\
\hline & & 113 & .680 \\
\hline & & 114 & .668 \\
\hline \multirow[t]{3}{*}{ PLATTVILLE } & RIVERSIDE & 110 & 1199873.331 \\
\hline & & 113 & .334 \\
\hline & & 114 & .325 \\
\hline \multirow[t]{2}{*}{ BLOOMINGTON } & ROCK & 117 & 512540.068 \\
\hline & & 120 & .050 \\
\hline \multirow[t]{2}{*}{ BLOOMINGTON } & NORTH LIBERTY & 117 & 517587.935 \\
\hline & & 120 & .942 \\
\hline \multirow[t]{2}{*}{ BLOOMINGTON } & WILLIAMSPORT & 117 & 270983.225 \\
\hline & & 120 & .266 \\
\hline \multirow[t]{2}{*}{ BLOOMINGTON } & FREELAND & 117 & 522595.520 \\
\hline & & 120 & .493 \\
\hline \multirow[t]{3}{*}{ BLOOMINGTON } & ASHCOPORT & 123 & 569800.483 \\
\hline & & 126 & .491 \\
\hline & & 127 & .502 \\
\hline \multirow[t]{3}{*}{ BLOOMINGTON } & BOLTON & 123 & 298136.947 \\
\hline & & 126 & .951 \\
\hline & & 127 & .964 \\
\hline \multirow[t]{2}{*}{ BLOOMINGTON } & STANPORT & 123 & 274427.356 \\
\hline & & 126 & .348 \\
\hline
\end{tabular}




\begin{tabular}{|c|c|c|c|}
\hline FROM & TO & DAY & VECTOR LENGTH \\
\hline & & 127 & .354 \\
\hline \multirow[t]{2}{*}{ BLOOMINGTON } & T007 & 126 & 584591.868 \\
\hline & & 127 & .894 \\
\hline \multirow[t]{2}{*}{ MARYLAND POINT } & T007 & 130 & 227234.678 \\
\hline & & 133 & .604 \\
\hline \multirow[t]{3}{*}{ MARYLAND POINT } & PRINCETON & 130 & 315398.013 \\
\hline & & 133 & .004 \\
\hline & & 134 & .032 \\
\hline \multirow[t]{3}{*}{ MARYLAND POINT } & ASTROWEST & 130 & 22712.616 \\
\hline & & 133 & .607 \\
\hline & & 134 & .635 \\
\hline \multirow[t]{2}{*}{ MARYLAND POINT } & BEARTOWN & 130 & 216972.580 \\
\hline & & 134 & .610 \\
\hline \multirow[t]{2}{*}{ HAYSTACK OCP3 } & ALBURG & 137 & 292459.638 \\
\hline & & 140 & .554 \\
\hline \multirow[t]{2}{*}{ HAYSTACK OCP3 } & ARP2 & 137 & 397900.907 \\
\hline & & 140 & .864 \\
\hline \multirow[t]{2}{*}{ HAYSTACK OCP3 } & K169 & 137 & 343693.732 \\
\hline & & 140 & .726 \\
\hline \multirow[t]{2}{*}{ HAYSTACK OCP3 } & LIME & 137 & 475062.190 \\
\hline & & 140 & .137 \\
\hline
\end{tabular}


TABLE 7

COMPARISON OF 1987 AND 1990 INTERSTATION VECTORS

\begin{tabular}{|c|c|c|c|c|c|}
\hline STATION PAIR & YEAR & DAY & $\begin{array}{l}\text { INTERSTATION } \\
\text { VECTOR LENGTH } \\
\text { (METERS) }\end{array}$ & $\begin{array}{l}\text { YEARLY MEAN } \\
\text { OF LENGTH } \\
\text { (METERS) }\end{array}$ & $\begin{array}{l}\text { DIFFERENCE } \\
\text { BETWEEN MEANS } \\
\text { (CM) }\end{array}$ \\
\hline \multirow[t]{7}{*}{ CARR TO GP37 } & 1987 & 322 & 223182.312 & & \\
\hline & & 323 & .270 & & \\
\hline & & & & 223182.291 & \\
\hline & 1990 & 82 & 223182.260 & & \\
\hline & & 85 & .322 & . & 1.1 \\
\hline & & 86 & .257 & & \\
\hline & & & & 223182.280 & \\
\hline \multirow[t]{8}{*}{ CARR TO GP47 } & 1987 & 321 & 467524.803 & & \\
\hline & & 322 & .824 & & \\
\hline & & 323 & .832 & & \\
\hline & & & & 467524.820 & \\
\hline & 1990 & 82 & 467524.825 & & \\
\hline & & 85 & .878 & & 1.8 \\
\hline & & 86 & .812 & & \\
\hline & & & & 467524.838 & \\
\hline \multirow[t]{7}{*}{ CARR TO GP57 } & 1987 & 322 & 360499.052 & & \\
\hline & & 323 & .200 & & \\
\hline & & & & 360499.126 & \\
\hline & 1990 & 82 & 360499.190 & & \\
\hline & & 85 & .247 & & 8.3 \\
\hline & & 86 & .189 & & \\
\hline & & & & 360499.209 & \\
\hline \multirow[t]{3}{*}{ CARR TO HAGO } & 1987 & 321 & 423466.742 & & \\
\hline & & 322 & .741 & & \\
\hline & & 323 & .806 & & \\
\hline
\end{tabular}

NUREG/CR - 6473 


\begin{tabular}{|c|c|c|c|c|c|}
\hline STATION PAIR & YEAR & DAY & $\begin{array}{l}\text { INTERSTATION } \\
\text { VECTOR LENGTH } \\
\text { (METERS) }\end{array}$ & $\begin{array}{l}\text { YEARLY MEAN } \\
\text { OF LENGTH } \\
\text { (METERS) }\end{array}$ & $\begin{array}{l}\text { DIFFERENCE } \\
\text { BETWEEN MEANS } \\
\text { (CM) }\end{array}$ \\
\hline & & & & 423466.763 & \\
\hline & 1990 & 78 & 423466.748 & & \\
\hline & & 79 & .724 & & 2.7 \\
\hline & & & & 423466.736 & \\
\hline \multirow[t]{6}{*}{ CARR TO WALT } & 1987 & 321 & 422783.341 & & \\
\hline & & 323 & .361 & & \\
\hline & & & & 422783.351 & \\
\hline & 1990 & 78 & 422783.344 & & 3.6 \\
\hline & & 79 & .287 & & \\
\hline & & & & 422783.315 & \\
\hline \multirow[t]{7}{*}{ CARR TO FLNR } & 1987 & 321 & 513397.142 & & \\
\hline & & 322 & .143 & & \\
\hline & & 323 & .085 & & \\
\hline & & & & 513397.123 & \\
\hline & 1990 & 68 & 513397.079 & & \\
\hline & & 72 & .024 & & 8.9 \\
\hline & & & & 513397.034 & \\
\hline \multirow[t]{7}{*}{ MDPT TO BEAR } & 1987 & 326 & 216972.608 & & \\
\hline & & 327 & .603 & & \\
\hline & & 328 & .617 & & \\
\hline & & & & 216972.609 & \\
\hline & 1990 & 130 & 216972.580 & & 1.4 \\
\hline & & 134 & .610 & & \\
\hline & & & & 216972.595 & \\
\hline \multirow[t]{2}{*}{ MDPT TO T007 } & 1987 & 326 & 227234.692 & & \\
\hline & & 327 & .665 & & \\
\hline
\end{tabular}




\begin{tabular}{|c|c|c|c|c|c|}
\hline STATION PAIR & YEAR & DAY & $\begin{array}{l}\text { INTERSTATION } \\
\text { VECTOR LENGTH } \\
\text { (METERS) }\end{array}$ & $\begin{array}{l}\text { YEARLY MEAN } \\
\text { OF LENGTH } \\
\text { (METERS) }\end{array}$ & $\begin{array}{l}\text { DIFFERENCE } \\
\text { BETWEEN MEANS } \\
\text { (CM) }\end{array}$ \\
\hline & & 328 & .696 & & \\
\hline & & & & 227234.684 & \\
\hline & 1990 & 130 & 227234.678 & & 4.3 \\
\hline & & 133 & .604 & & \\
\hline & & & & 227234.641 & \\
\hline \multirow[t]{8}{*}{ MDPT TO PRIN } & 1987 & 326 & 315398.046 & & \\
\hline & & 327 & .034 & & \\
\hline & & 328 & .027 & & \\
\hline & & & & 315398.036 & \\
\hline & 1990 & 130 & 315398.013 & & 2.0 \\
\hline & & 133 & .004 & & \\
\hline & & 134 & .032 & & \\
\hline & & & & 315398.016 & \\
\hline \multirow[t]{7}{*}{ BLOO TO BOLT } & 1987 & 336 & 298136.944 & & \\
\hline & & 337 & .933 & & \\
\hline & & & & 298136.939 & \\
\hline & 1990 & 123 & 298136.948 & & \\
\hline & & 126 & .951 & & 1.5 \\
\hline & & 127 & .964 & & \\
\hline & & & & 298136.954 & \\
\hline
\end{tabular}




\section{TITLE AND SUBTITLE}

Global Positioning System Reobservations over the Fastern United States

Strain Monitoring Network

5. AUTHOR(S)

William E. Strange

\begin{tabular}{l|c} 
3. DATE REPORT PUBLISHED \\
MONTH & YEAR \\
June & 1996
\end{tabular}

4. FIN OR GRANT NUMBER

D1749

6. TYPE OF REPORT

Technical

7. PERIOD COVERED (Inelusive Dates)

March 1990 - December 1992

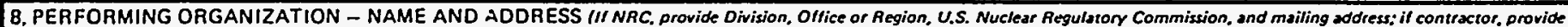
name and mailing address)

National Geodetic Survey

National Oceanic and Atmospheric Administration

1315 East-West Highway

Silver Spring, MD 20910

9. SPONSORING ORGANIZATION - NAME AND ADDRESS III NAC, trpe "Same as above" ;Il contractor, provide NRC Division. Office or Region, U.S. Nuclear Regulatory Commission, and mailing sddress,

Division of Engineering Technology

Office of Nuclear Regulatory Research

U.S. Nuclear Regulatory Commission

Washington, DC 20555-0001

10. SUPPLEMENTARY NOTES

E. Zurflueh, NRC Project Manager

11. ABSTRACT 1200 words or kess)

In the period March-May, 1990, a 45 station geodetic network, originally established in Novenber-December, 1987, was reobserved using global positioning system (GPS) technology. This network, known as the Fastern U.S. Strain Network, was established for the purpose of determining strain and deformation in the central and eastern United States. This 1990 reobservation was the first of a series of reobservations scheduled to take place over a decade in order to place meaningful constraints on the small differential movements involved.

GPS

Crustal Strain

Untimited

14. SECURITY CLASSIFICATION

IThis Pasel

Unclassified

(This Repor)

Unclassified

15. NUMBER OF PAGES

16. PRICE 


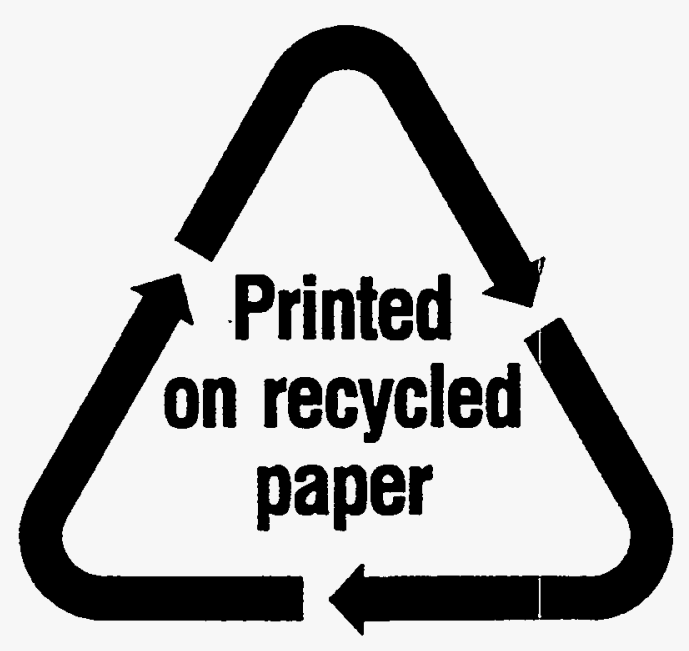

Federal Recycling Program 